\section{The Effect of Conceptual Change Texts on the Level of Conceptual Understanding of Students}

\author{
Burcu Sel ${ }^{a, *}$, Mehmet Akif Sözer ${ }^{b}$
}

\begin{tabular}{ll}
\hline Received: & 20 November 2018 \\
Revised: & 13 February 2019 \\
Accepted: & 25 February 2019 \\
ISSN: 1307-9298 \\
Copyright (C) IEJEE \\
www.iejee.com
\end{tabular}

DOI: 10.26822/iejee.2019450796

\begin{abstract}
This study aimed to investigate the effect of conceptual change texts on the conceptual understanding of local government concepts pertinent to the "power, management and society" learning field, as well as the "People and Administration" unit on the fourth-grade social studies course. In the study, a semi-experimental design with pre-/post-test control groups was adopted and samples were obtained from easily accessible samples from non-probability sampling types. The sample consisted of 34 students. As a means of collecting data, a two-stage conceptual understanding test was employed for the level of conceptual understanding, as developed by the researcher. In the analysis of data, dependent group/independent groups' t-test and covariance analysis were employed. It was found that the achievement scores of the last test made after the experimental process, based on the conceptual change texts, yielded a significant difference in favour of the experimental group. As a result of the research, in comparison with the activities carried out according to the current curriculum, it is possible to say that the conceptual change texts make a positive contribution to the level of the conceptual understanding of the students.
\end{abstract}

Keywords: Conceptual Change, Misconception, Social Studies

\section{Introduction}

As a requirement of constructivist education understanding, it is of utmost importance that the individuals constructing knowledge can make information permanent and transfer it to daily life through various abstractions, understandings, analyses and constructs that make up knowledge. Concept teaching is becoming more and more attractive in lessons, especially in forms of social studies that are multidimensional and have a content integrity that can be directly related to interdisciplinary and daily life, while being placed on concept-value-skill grounds. It is accepted that an important precondition about learning and constructing basic concepts pertain to the fields that are alluded to in the understanding and assessment of many economic, social, cultural, global and historical processes, which constitute the core of social studies courses. The social sciences curriculum seeks to find ways of attributing "acceptable" significance to the social order and the world that individuals move through (MoNE, 2005). In this respect, as a requirement of the content of social studies courses, students who encounter different concepts related to many fields might face erroneous perceptions of basic concepts or construct imperfections; as a requirement of the spiral curriculum, many misconceptions or mislearning in future periods occur.

The qualitative execution of the conceptual teaching process requires a systematic analysis of the nature and the multiple viewpoints of the "concept". In this context, there are many different definitions, stages and classifications related to concepts. Öner (1986) classified concepts in terms of how they are handled in terms of the individual universal, singular and abstract/collective, and abstract/collective/positive and negative, as well as essential (relative) and correlative (faulty) in relation to each other. Concepts can be defined as the basic building blocks of the thought life of individuals during their lifetime (Dündar, 2011). Concepts are the abstraction of one or more characteristics of a particular stimulus (Morgan, 1977). In the most general sense, "concepts" are mental structures that represent the processes of organizing similar objects, events, situations, thoughts and actions (Klausmeier, 1992). However, the most basic dimension that is particularly expressed in concept teaching is the "abstraction skill" period. Abstraction skills have an important role to play in high-level thinking, generalizability, inter-conceptual relations, hypothesis testing and organizing knowledge. In addition, stages in the concept teaching model are classified as presentation of examples, formation and analysis of hypotheses, closure, application (Kilbane \& Milman, 2013).

In educational processes, in addition to concept teaching, conceptual understanding and the elimination of conceptual misconceptions are also of great importance. Especially, when determining and eliminating alternative concepts and contradictory concepts that are contradictory to scientific reality, conceptual change in the desired direction is dependent on a number of factors. When the literature is examined, it can be seen that there are various nomenclatures for the conceptual change process. In the process of conceptual change, there is a gradual change in mental models of the individual's physical world, either in terms of revision or by various enrichments. Enrichment involves adding information to existing conceptual constructs. Revision may require changes to individual beliefs or assumptions, or changes in the relational structure of a theory (Vosniadou, 1994). The conceptual change process is the elimination of existing conceptual misconceptions and the observation and modification of misconceptions in order for significant learning to take place (Smith, Disessa \& Rochelle, 1993). Conceptual change in a general sense is a term that shows the way of learning from students' pre-learning thoughts to new scientific concepts to be learned (Duit \& Treagust, 2003). Conceptual change is most useful when they provide students with the opportunity to critically assess scientific evidence in comparison with their previous knowledge (Broughton, Sinatra \& Nussbaum, 2013). Although there are different conceptions about the conceptual change process, the general expectation is that the original conceptions of the students take place among scientific conceptions (Mortimer, 1995). The conceptual change is the creation of learning by powerful- 
ly restructuring young or adult individuals' thoughts about something. For example, it can be argued that conceptual change appeared when small children began to understand the earth globally, setting aside the idea that the earth is flat (Dole, 2000). On the other hand, the recent debates and criticisms of the conceptual change process relates to the "what" of the conceptual change. As Mortimer (1995) has pointed out, "conceptual change" as a constructivist understanding has been "transformed into a label that encompasses many different and sometimes inconsistent views" (p. 267). It is also criticized by Vosniadou (2007) for its over-emphasis in terms of mental contradiction.

In the conceptual change model, learning does not simply involve the insertion of new pieces of information into existence, but the interaction of existing information with new knowledge; in other words, it is possible to reconcile existing knowledge with new knowledge wherever possible (Hewson \& Hewson, 1983). In this understanding, there are three important steps for new knowledge to integrate itself with existing knowledge and satisfy the student:

The first is that the new concept is understandable; in other words, it is the person who knows what the new concept is and creates a consistent representation of the concept.

Secondly, it is considered as an absolute conviction that the new concept is reasonable and can be rectified. The last is that the concept serves to solve problems and presents new approaches (Hewson \& Hewson, 1983). However, as pointed out by Posner, Strike, Hewson and Gertzog (1982), there are four important stages for the conceptual change process to take effect:

- Dissatisfaction: The concept that is present in the mind of the student is incomplete/inadequate.

- Intelligibility: The new concept for the student is "understandable".

- Plausibility: The new concept for the student is logical and consistent with other concepts.

- Fruitfulness: The use of the new concept in any situation or problem that the student has encountered.

In order for the conceptual change process to take place, it is necessary to identify the misconceptions/alternative concepts in the information by revealing the prior knowledge of the student and to make the student feel the inadequacy of these misconceptions.

The mental conflicts/cognitive contradictions, which will be experienced when students face the concepts scientifically verified by the conceptual change texts (CCTs), are considered an important tool in the process of overseeing and regulating the new concept to be acquired.

Research on texts based on the conceptual change approach has mostly been used in science education in the domestic and international literature. Özdemir (2012) investigated the effectiveness of CCTs in relation to achievement, attitude and motivation in fifth-grade science and technology lessons according to different learning styles, resulting in an increase in the conceptual achievement levels of students. In the research conducted by Çaycı (2007), the influence of CCTs on the significance and science of classroom teacher candidates was examined and the positive impact of the conceptual change approach on the achievement of the achievement was observed, but it was determined that the effect on attitudes was not affected. In Altuntaş-Aydın's (2011) study, the effect of model and CCTs on student achievement and conceptual change effects were investi- gated; it was been found that the method used positively contributes to improving conceptual misconceptions and increasing achievement.

The effect of CCTs, enriched by key conceptual activities, on the conceptual understanding levels, attitudes and permanence of science and technology teacher candidates was investigated by Demir (2010), who determined a positive influence on conceptual understanding and sustenance. In the study conducted by Akpınar (2012), it was determined that CCTs had a positive effect on student access in a context-based approach based on the 5E model. In the study on the conceptual achievement and the effects of CCTs during eighth-grade science and technology lessons by Sarı Ay (2011), the positive effect of achievement and conceptual misconceptions was revealed in the study. In the study conducted by Akgül (2010) among science and technology teacher candidates, the level of the conceptual understanding of CCTs, enriched by upper conceptual activities, as well as the persistence and the positive effect of sustenance, was put forward. A meta-analytical study was conducted by Öner Armağan (2011) on the effectiveness of CCTs, which concluded that CCTs are more effective than traditional teaching methods.

Studies in which the CCTs are used in the teaching of social studies are quite limited. In the study conducted by Türksever (2013), the positive effects of CCTs in determining and rectifying the misconceptions of CCTs in geography teaching were put forward. Akbaş, Koca and Cin (2012) reached the conclusion that CCTs had a positive effect on the conceptual misconceptions in ninth-grade geography teaching. Aladağ and YIlmaz (2014) examined the effectiveness of CCTs in fourth-grade social studies classes and found that these texts had a positive effect on the elimination of misunderstandings about concepts.

In the research conducted by Kılıçoğlu (2011), the effect of CCTs, when applied to certain concepts in the sixth-grade social studies curriculum was investigated. The researcher reached the conclusion that CCTs made a positive effect on the level of achievement and the elimination of misconceptions about the concept. However, it is seen that, in the course of social studies, the misconceptions about the concept can be determined by methods such as concept maps, concept cartoons and concept nets, which are gradually becoming stereotyped and standardized. Moreover, although there is a limited number of conceptual change-based studies in the field of social studies, it is possible to observe that CCTs are developed more towards science concepts. The social sciences course provides a rich and solid background in terms of the scope of the political concepts in which cognitive contradictions take place, as well as the awareness of them, self-regulation and restructuring of concepts. It is believed that the application of CCTs in the social studies field and political concepts could contribute to the literature. In this context, the study provides an important example of the effectiveness of the conceptual change texts in identifying and eliminating misconceptions in social studies lesson. In addition, this study provides an example of how teachers use conceptual change texts in primary school.

The purpose of this research is to determine the effect of CCTs on the conceptual understanding level of students in the learning strand of the "power, management and society" and "people and administration" (local and central administration) units on the fourth-grade social studies course. In response to this objective, answers to the following questions were sought:

- What are the current conceptual misconceptions among students in the experimental and control groups regarding the concepts of local administration and central administration? 
- Is there a significant difference between the conceptual understanding level of pre-test and posttest achievement scores of the students in the experimental group whose learning is based on the CCTs in the social studies class?

- Is there a significant difference between the level of the conceptual comprehension of pre-test and post-test achievement scores of the control group students, based on the current curriculum in the social studies class?

- Is there a significant difference between the posttest scores of the experimental and control groups when pre-test scores are recognized as constant?

\section{Materials and Methods}

In the study, a pre-test/post-test control group semi-experimental design was adopted from experimental models. As stated by Karasar (2009), "experimental models are research models in which the aim is to determine causeand-effect relationships and produce the data to be observed under the direct researcher's control".

The research process involved the "People and Administration" unit, while the activities based on the current curriculum were carried out among the control group. Activities related to the CCTs prepared by the researcher for the experimental group were applied during the four-hourlong course. In this context, the following table sets out the experimental pattern applied in the research process:

Table 1. Pattern for the experimental model used in the research

\begin{tabular}{ccccc}
\hline Groups & Pre-test & $\begin{array}{c}\text { Experimental } \\
\text { Process }\end{array}$ & $\begin{array}{c}\text { Processing } \\
\text { Time }\end{array}$ & Post-test \\
\hline Experiment & $\begin{array}{c}\text { Two-stage } \\
\text { Achievement } \\
\text { Test(1) }\end{array}$ & CCTs & $\begin{array}{c}4 \text { lesson hours } \\
40+40+40+40 \\
\text { minutes }\end{array}$ & $\begin{array}{c}\text { Two-stage } \\
\text { Achievement } \\
\text { Test(2) }\end{array}$ \\
\hline Control & $\begin{array}{c}\text { Two-stage } \\
\text { Achievement } \\
\text { Test(1) }\end{array}$ & $\begin{array}{c}\text { Current } \\
\text { Programme- } \\
\text { based } \\
\text { Activities }\end{array}$ & $\begin{array}{c}4 \text { lesson hours } \\
40+40+40+40 \\
\text { minutes }\end{array}$ & $\begin{array}{c}\text { Two-stage } \\
\text { Achievement } \\
\text { Test(2) }\end{array}$ \\
\hline
\end{tabular}

The experimental and control groups were pre-tested as a two-step achievement test, which was prepared by the researcher during one lesson hour; then, activities based on CCTs were carried out by the researcher. In the process of preparing the CCTs related to the experimental process, literature on the subject of "people and management" was researched and a projection about conceptual misconceptions and levels of understanding was attempted and a limited number of studies was identified (Doğan, 2007; Topçubaşı \& Polat, 2014). Next, a fourth-grade social studies textbook prepared by different publishers and the 2017 fourth-grade social studies curriculum were examined. In addition, the students were asked to complete the two-step test, and a list of the preliminary information that led to the conceptual misconceptions was made. This was an important prerequisite for the identification of the cognitive contradictions that students have in a conceptual change process and for the awareness of conceptual misconceptions.

While CCTs were created, the factors of inadequacy, comprehensibility, reasonableness and efficiency, which were determined by Posner et al. (1982), were considered. At the dissatisfaction stage, students' sentences containing misconceptions were inserted as text into cartoons, while, using current Internet news and diagrams, questions were asked about why the misconceptions were caused. By illustrating the concepts, attention was drawn to the cog- nitive contradictions and mental conflicts of the students. Then, in the section called "Stop and Think", the students were presented with various examples of the missing reality from the misconceptions, with the specific expressions to be highlighted written in colour, bold, italic and large font sizes. In turn, the stage of intelligibility was completed using cartoons and visuals. In the third stage, the "Text Reading" sections were established in order to be able to work on the alluded concepts behind the case studies, which students may have encountered in daily life and to adapt them to existing schemes. Thus, the plausibility phase was completed. Subsequently, the necessity of local and central administrations and the sub-dimensions related to these concepts were reflected in relation to daily life and the existing management system.

In the "Order!" section, once the concept was internalized and evaluated using various questions, the fruitfulness phase was completed. After the aforementioned preparation period, five students were invited to pre-read, and the long sentences were shortened, and the text was simplified. Then, by applying a Turkish perspective, two primary school teachers and a teacher in social studies extracted unnecessary repetitions and visual elements, which disturbed the flow.

While the experimental group was performing the experimental process with the CCTs, the control group was instructed to undertake the activities based on the existing curriculum. The same dependent variable (conceptual comprehension) was observed in both groups.

Both groups then performed a two-stage achievement test as a final test during a one-hour session. Pre-test and post-test scores were compared both between groups and in the groups.

\section{Study group}

The sample (study group) selected for the study constituted a total of 34 students from the fourth grade in a primary school in Ankara during the academic year 2016-2017. In the study, a pre-test/post-test control group semi-experimental design was adopted from experimental models. In the semi-experimental design; control and experimental groups cannot be selected randomly. However, the groups must have similar properties. Therefore, two classes with achievement levels close to each other were preferred (Table 3). One of these classes was randomly determined as (4-A) and the other as control group (4-B). In this context, the frequencies and percentages of the gender of the students in the sample are as indicated in Table 2:

Table 2. Frequency and percentage ratios of the gender of students in the sample group

\begin{tabular}{ccccc}
\hline & \multicolumn{2}{c}{ 4/A Grade } & \multicolumn{2}{c}{ 4/B Grade } \\
\hline & Frequency $(f)$ & Percentage (\%) & Frequency $(f)$ & Percentage (\%) \\
\hline Girl & 8 & 47.05 & 9 & 52.95 \\
\hline Boy & 9 & 52.95 & 8 & 47.05 \\
\hline Total & 17 & 100 & 17 & 100 \\
\hline
\end{tabular}

Pre-test conceptual comprehension scores were compared in the groups' equivalence study and the obtained results are shown in Table 3.

When Table 3 is examined, it can be seen that there is no statistically significant difference between the average scores of the experiment and control groups obtained from the preliminary test $\left(t_{(32)}=0.479 ; p>.05\right)$. This finding can be interpreted as confirmation that the preliminary knowledge among the students concerning the conceived concept was close in relation to each other. 
Table 3. T-test Results on the results obtained from the preliminary test by the experimental and control group

\begin{tabular}{ccccccc}
\hline Group & $N$ & $M$ & $s d$ & $D f$ & $t$ & $p$ \\
\hline Experiment Group & 17 & 9.88 & 1.409 & 32 & .479 & $.635^{*}$ \\
\hline Control group & 17 & 9.64 & 1.450 & & & \\
\hline${ }^{*} p<0.05$ & & & & & &
\end{tabular}

\section{Data Collection Tools}

A two-stage achievement test was developed by the researcher to be used in the pre-test and post-test periods, taking into consideration the purpose of the study. The first part of the two-step test consists of four alternative questions, and the second part consists of open-ended questions where students are asked to explain the answers given in the first part. The first part of the two-step test consists of four alternative questions, and the second part consists of open-ended questions where students are asked to explain the answers given in the first part. The most distinctive feature that distinguishes two-step tests from multiple-choice tests is the second step in the second part of the test, in which a response in the first part is requested (Chen, Lin \& Lin, 2002; Karataş, Köse, \& Çoştu, 2003). In this sense, a 27item question pool was established to determine conceptual misconceptions in the "People and Management" unit and the level of understanding.

For each question, three of the options include misconceptions about the "People and Administration" unit, while the remaining option includes the rectified answer.

In the writing phase for the questions, social studies textbooks and workbooks published by different publishing houses in different years were examined, and studies on local government and central administration concepts were analysed in the summer. On the curriculum, the achievements related to these concepts were examined and Bloom's taxonomy was used, while a 27-item question pool overlapped with the gains. At the same time, a table of notations as shown in Table 4 was prepared to increase the coverage of the study.

Table 4. Establishment of the notation table for the achievement test

\begin{tabular}{|c|c|c|c|c|c|c|c|}
\hline 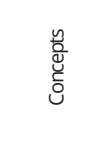 & 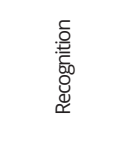 & 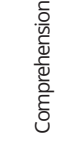 & 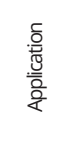 & 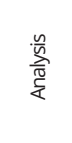 & 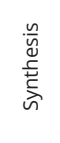 & 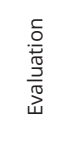 & 宽 \\
\hline Municipality & 8,17 & $6,11,26$ & 1.409 & 15,21 & .479 & $.635^{*}$ & $\begin{array}{c}7 \\
\text { questions }\end{array}$ \\
\hline Mukhtar & & $\begin{array}{c}3,5,10, \\
18\end{array}$ & 1.450 & 13 & & & $\begin{array}{c}5 \\
\text { questions }\end{array}$ \\
\hline $\begin{array}{l}\text { Local } \\
\text { Administ. }\end{array}$ & $\begin{array}{c}20,1,2,9,12 \\
14,16,20\end{array}$ & 14,24 & & 19,27 & & & $\begin{array}{c}12 \\
\text { questions }\end{array}$ \\
\hline Election & $4,7,25$ & & & & & & $\begin{array}{c}3 \\
\text { questions }\end{array}$ \\
\hline Total & & & & & & & $\begin{array}{c}27 \\
\text { questions }\end{array}$ \\
\hline
\end{tabular}

It was also noted that similar questions should not be repeated in order to avoid similar questions directing the students. The prepared questionnaires were examined by an area specialist and a social studies teacher and agreed upon, with the necessary arrangements made. Within the scope of the fourth-grade social studies course, the preliminary application of the conceptual achievement test for 12 students was carried out. The students were informed about the properties related to the pre-implementation test (purpose of the test, number of questions, response style etc.). After the pilot implementation by the researcher, sentence and question roots, which were difficult to understand, were rearranged and long sentences were abbreviated. However, Items 6, 13 and 23 had a low discriminatory index, Item 7 was easy according to the difficulty index, and Items 6, 14 and 27 werefound to be hard and removed from the test.

The KR-20 reliability coefficient of the conceptual achievement test, which was pre-applied by using the SPSS program in terms of reliability, was found to be 71. After all these processes, the test was transformed into a two-stage test consisting of 20 items. Sample of item is as follows:

"Which of the following is not among the local government units?

a) Special Provincial Administration

b) School Administration

c) Municipalities

d) Mukhtars

Because...

\section{Analysis of Data}

In the analysis of data, the first problem was analysed and the percentage (\%) and frequency $(f)$ values were determined to evaluate misconceptions and their frequency of occurrence. In the data analysis process related to other sub-problems, it was examined whether the data showeda normal distribution or not. Regarding the scores from the experimental and control groups, skewness and kurtosis coefficients and Kolmogorov-Smirnov and Shapiro-Wilk tests were used.

Table 5. Data relating to skewness and kurtosis coefficients

\begin{tabular}{ccc}
\hline & Skewness & Kurtosis \\
\hline Experimental Group & -.374 & -.367 \\
\hline Control Group & .014 & -.747 \\
\hline
\end{tabular}

When the skewness and kurtosis coefficients in Table 5 are examined, it can be seen that the scores do not deviate from the normal distribution. It may be pointed out that scores have normal distribution if the values for skewness and ridge indicate a value between -1.5 and +1.5 (Tabachnick \& Fidell, 2007).

Table 6. Data relating to the Kolmogorov-Smirnov and Shapiro-Wilk tests

\begin{tabular}{ccccccc}
\hline & \multicolumn{3}{c}{ Kolmogorov-Smirnov } & \multicolumn{3}{c}{ Shapiro-Wilk } \\
\hline & Statistic & Df & Sig. & Statistic & Df & Sig. \\
\hline Experimental & .180 & 17 & 144 & 945 & 17 & .384 \\
\hline Control & .142 & 17 & 200 & 951 & 17 & .467 \\
\hline
\end{tabular}

It can be seen that the pre-test scores for the experimental and control groups show normal distribution according to Table $6(p>.05)$. For this reason, parametric tests were used in the data analysis process.

However, in the analysis of the data obtained from the twostage achievement test, dependent group and independent group $t$-tests were used. The independent group $t$-test was used for the second sub-problem, while the dependent group t-test was used in the analysis of the third and fourth sub-problems in order to test the effect of the experimental process in the studies in which the pre-test/post-test control group semi-experimental design was adopted. In the analysis of the fifth sub-problem, covariance analysis was used to determine whether the difference between the post-test scores was significant, as the pre-test scores for the groups remained constant. 


\section{Results and Discussion}

The data were analysed by considering the purpose and sub-problems of the study; the findings of each sub-problem are given below.

Current Conceptual Misconceptions of Students in Experimental and Control Groups Related to Local and Central Government Concepts

The misconceptions that students have concerning the "People and Administration" unit on the fourth-grade social studies course were determined by the analysis of the justification sections, starting with "because...", in the open-ended section of the two-stage test. In this respect, the misconceptions of the students were expressed as shown in Figure 1.

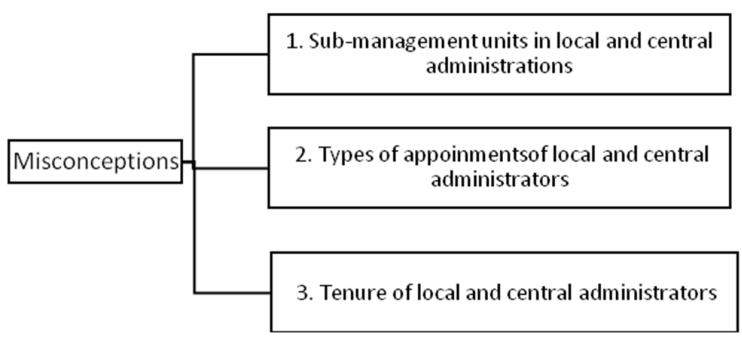

Figure 1. Misconceptions about the Concepts that Students Have About the "People and Administration" Unit

Items 1, 6, 12, 14, 16 and 19 in the two-stage conceptual understanding test related to the first conceptual misconception, Items 4, 7, 9 and 18 related to the second conceptual misconception and Items 13 and 20 related to the third conceptual misconception.

Table 7. Prevalence of misconceptions among the experiment and control group students

\begin{tabular}{ccccccccc}
\hline & $\begin{array}{c}\text { 1stConceptual } \\
\text { Misconception }\end{array}$ & \multicolumn{2}{c}{$\begin{array}{c}\text { 2ndConceptual } \\
\text { Misconception }\end{array}$} & $\begin{array}{c}\text { 3rd Conceptual } \\
\text { Misconception }\end{array}$ & \multicolumn{2}{c}{ Total } \\
\hline & $f$ & $\%$ & $f$ & $\%$ & $f$ & $\%$ & $f$ & $\%$ \\
\hline $\begin{array}{c}\text { Experiment } \\
\text { Group }\end{array}$ & 21 & 44.68 & 14 & 29.78 & 12 & 25.53 & 47 & 100 \\
\hline $\begin{array}{c}\text { Control } \\
\text { Group }\end{array}$ & 18 & 43.90 & 17 & 41.46 & 6 & 14.63 & 41 & 100 \\
\hline
\end{tabular}

It has been observed that the students had various misconceptions concerning the classifications of the sub-governing units in local and central administrations. Some students defined governorships and district governments as local governments, while other students defined municipalities and mukhtars as central administrations. In addition, some institutions, such as associations, foundations or hospitals, have been classified as local/central government units by certain students.

Examples of misconceptions among students in the experimental and control groups in terms of "sub-governing bodies" in local and central administrations are as follows:

$$
\begin{aligned}
& K_{3}: \text { "Because the governor is the greatest local ruler in the } \\
& \text { county, he will rule us." } \\
& K_{11}: \text { "Because schools are governed." } \\
& D_{8}: \text { "Because district governors work in local government, } \\
& \text { they build the roads." }
\end{aligned}
$$

$D_{12}$ : "Because the mukhtars are people working in the centre, they go to villages from the centre."

$D_{16}:$ "Because the mukhtars go everywhere from the centre, they help people there."
The conceptual category of "appointing local and central administrators" is the most intensive misconception category. In particular, it has been observed that some students have misconceptions about the concepts of "election and appointment" (governor/district governor) and the administrators elected by the public (mukhtar/mayor). Examples of conceptual misconceptions among administrators involved in local and central administrations regarding the election and appointment are as follows:

$K_{8}:$ "Because the mukhtars inform the municipality about sanitation jobs in the neighbourhood. Because the municipality chooses the mukhtar."

$K_{12}$ : "Because the president appoints the mayor in the most appropriate manner."

$K_{15}$ : "For me, the governor chooses the mukhtar and the mayor, because he is the greatest."

$D_{1}$ : "For me, our mayor chooses the mukhtar."

$D_{g}$ : "Because the mayor is not elected, he is appointed by the government."

The misconceptions that students in the local and central administrations have about the term of office are related to how long the elections are held, how long the local administrators can be in service, and the term of office of the administrators in the central administration. Examples of misconceptions that students have about the tenure of local and central administrators are as follows:

$K_{3}$ : "Because, according to me, the mukhtars serve for three years, then they change."

$K_{4}:$ "Because the mayor can serve an unlimited term of office after being elected by the Prime Minister."

$K_{14}:$ "Because no one chooses the mukhtar, he will serve two years freely if he wants to."

$D_{5}:$ " Because, for me, governors and district governors may change after three years."

$D_{10}:$ "Because the district governor is elected every five years, like the mukhtar."

Comparison of Pre-test and Post-test Scores of the Students in the Experimental Group

The dependent group t-test was used to determine whether there was a significant difference between the averages of the pre-test and post-test scores of the experimental group for the "People and Administration" unit; the findings are given in Table 8.

Table 8. T-test results on the findings obtained from the pretest and post-test by the experimental group

\begin{tabular}{ccccccc}
\hline Experiment Group & $N$ & $M$ & $s d$ & $d f$ & $t$ & $p$ \\
\hline Pre-test & 17 & 9.88 & 1.409 & 16 & 37.18 & $.000^{*}$ \\
\hline Post-test & 17 & 16.29 & 1.455 & & & \\
\hline
\end{tabular}

${ }^{*} p<0.05$

When Table 8 is examined, there is a statistically significant difference in favour of the post-test $\left(t_{(16)}=37.18\right.$; $p<$ .05 ) when the pre-test and the post-test scores of students in the experimental group are compared. In addition, the arithmetic mean $(M=16.29)$ of the scores obtained from the final test involving the experimental group regarding the concepts in the "People and Management" unit was higher than the arithmetic mean of the scores obtained from the pre-test $(M=9.88)$. This situation can be interpreted as a positive effect on the level of conceptual understanding of teaching based on the CCTs. 
Comparison of Pre-test and Post-test Scores of the Students in the Control Group

The dependent group t-test was used to determine whether there was a significant difference between the mean of the pre-test and post-test scores of the control group in the "People and Administration" unit, with the findings given in Table 9.

Table 9. The T-test results of the control group obtained from the pre-test and the post-test

\begin{tabular}{ccccccc}
\hline Control Group & $N$ & $M$ & $s d$ & $d f$ & $t$ & $p$ \\
\hline Pre-test & 17 & 9.64 & 1.409 & 16 & 37.18 & $.000^{*}$ \\
\hline Post-test & 17 & 11.35 & 1.455 & & & \\
\hline${ }^{*} p<.05$ & & & & & &
\end{tabular}

When Table 9 is examined, statistically significant differences were found in favour of the post-test when the pre-test and post-test scores of the control group students were compared $\left(t_{(16)}=37.18 ; p<.05\right)$. In addition, the arithmetic mean $(M=11.35)$ of the post-test scores obtained from the control group on the concepts in the "People and Management" unit was higher than the arithmetic mean of the pre-test scores $(M=9.64)$. This can be interpreted as a positive effect on the level of the conceptual understanding of teaching based on the current curriculum.

Comparison of the Post-test Scores of the Experimental and Control Groups When Pre-test Scores are Considered to be Constant

Covariance analysis was conducted to determine whether there was a significant difference between the post-test scores when the pre-test scores of the control and experiment groups for the "People and Administration" unit were kept constant. Primarily, the assumptions required for performing covariance analysis (normal distribution of data, homogeneity of group variances, and uniformity of regression coefficients) were tested, after which covariance analysis was undertaken. The results of the analysis are given in Table 10.

Table 10. Descriptive statistics for the mean of covariance analysis outcome for groups

\begin{tabular}{cccc}
\hline Group & $N$ & $M$ & Adjusted Average \\
\hline Experiment Group & 17 & 16.29 & 16.28 \\
\hline Control Group & 17 & 11.35 & 11.36 \\
\hline
\end{tabular}

When Table 10 is examined, with the average of 16.29 in the experimental group taken as the rectified average, the mean is 16.28; the control group's average of 11.35 has a rectified average of 11.36. It is seen that the adjusted average scores for the groups are higher in the experimental group. The covariance analysis results for determining whether the difference between the adjusted mean scores of the groups are truly significant are given in Table 11.

Table 11. Results of covariance analysis for post-test scores adjusted for pre-test scores

\begin{tabular}{cccccc}
\hline $\begin{array}{c}\text { Source of } \\
\text { Variance }\end{array}$ & $\begin{array}{c}\text { Total of } \\
\text { Squares }\end{array}$ & $s d$ & $\begin{array}{c}\text { Mean of } \\
\text { Squares }\end{array}$ & $F$ & $p$ \\
\hline Pre-test & .209 & 1 & .209 & .073 & .789 \\
\hline Group & 204.946 & 1 & 204.946 & 71.224 & $.000^{*}$ \\
\hline Error & 89.203 & 31 & 2.878 & & \\
\hline Total & 6.794 .000 & 34 & & & \\
\hline${ }_{p<0.05}$ & & & & &
\end{tabular}

As seen in Table 11, it can be seen that there is a significant difference in the experimental group between the final test average scores $\left(F_{(1-31)}=71,224 ; p<.05\right)$ for the experimental and control group students, when rectified for pre-tests. In addition, according to the results of the Bonferroni test performed on the adjusted average in the experimental and control groups, it can be seen that the adjusted average ( $M=$ 16.28) for the test group is higher than the rectified average score $(M=11.36)$ of the control group. Therefore, it can be said that the test scores of the experimental group students are higher than for the control group students.

\section{Conclusion}

When the social studies curriculum renewed in 2017 is examined, it can be seen that the conceptual teaching process holds an important place. In the "Competences" section of the curriculum, the importance of concept teaching in many fields, such as interaction in relation to mother tongue and foreign languages, competences in social citizenship is mentioned. Within this concept, it is recommended that different concept teaching classifications and approaches should be used, while misconceptions should be eliminated (MoNE, 2018). In this context, one of the effective methods used in the concept teaching process is the conceptual change texts. With its different system, CCTs, among the alternative methods, provide students with an interactive environment. Since they are based on students' prior knowledge and experience, the misconception behind CCTs, students' sense of concept, the comparison between concepts based on scientific reality and the misconceptions of existing concepts, when efficiently transferred to everyday processes by assimilating the concept based on scientific reality, the form of understanding is constructed on the basis of constructivist learning theory.

In this respect, in this study, when using CCTs on a fourthgrade social studies course, students enrolled on the "People and Administration" unit have many misconceptions about this unit. Especially in the context of local and central administration, students have a number of misconceptions regarding the duration of appointments, elections, sub-governing bodies and managers' duties. The research is consistent with the findings of the study conducted by Memişoğlu and Tarhan (2016) in terms of the misconceptions that social studies teachers intensively face in educational processes (management forms; centralized management concepts). However, the findings of the research are in parallel with the concept misconceptions (local government/municipality/election concepts) as realized by Bal and Akış (2010) and encountered in the "People and Administration" unit on the social studies course. Regarding the inadequacies of students in the pre-test process, the basic concepts of the "People and Management" unit are concerned with preliminary information not based on scientific grounds and alternative concepts, which these students have acquired from their daily lives and experiences. Pre-concepts that students may possess have a positive or negative effect on learning processes (Pintrich, Marx, \& Boyle, 1993). It is especially important to identify the prior knowledge and concomitant misconceptions. It is a long process to eliminate misconceptions that are resistant to change, even for students with high academic scores (Guzzetti, 2000). Misconceptions emerging from courses including numerous political concepts, such as social studies, gradually splice and then multiply. Similarly, in this research, the conceptual category of "appointing local and central administrators" is the most intensive political misconception category. In order to overcome misconceptions, new knowledge must be understandable and sensible for students (Hewson \& Hewson, 1983).

For this study, the effect of CCTs on the level of the conceptual understanding of students was examined; the conceptual misconceptions of CCTs and the positive effect on their achievement have been put forward. As a result of the research, it can be seen that the students in the experimental group had higher levels of understanding of the basic 
concepts of the "People and Administration" unit than the students in the control group, while more explanations based on scientific reality about the concepts were used. When the literature is examined, this research coincides with the end result of many studies showing that CCTs make positive contributions to increase levels of understanding and eliminate the misconceptions (Hewson \& Hewson, 1983; Wang \& Andre, 1991, Chambers \& Andres, 1997; Çaycı, 2007; Kılıçoğlu, 2011; Sarı-Ay, 2011; Akpınar, 2012; Özdemir, 2012).

The studies based on the CCTs in the field of social sciences have been dealt with in terms of an interdisciplinary approach, such as "climate, map, scale, weather and location", where social science and physical science intersect. The lack of literature on the use of CCTs concerning concepts addressed on political and ideological grounds, such as municipalities, reeves, local government and elections, does not enable the findings of the research to be extensively assessed in the light of other studies. However, in more recent social studies, concepts such as value, culture, national culture, tradition (Aladağ \& Yılmaz,2014), proof, chronology, century, tradition (Akşit, 2016) age, aesthetic, conquest, holy war, reform and settlement (Şarlayan, 2017) are used in conceptual change studies. When considering the stages of creating awareness among students about the reasons for conceptual errors, making students feel the current conceptual deficiencies, understanding and accepting the explanations based on scientific reality, comparing conceptual significance with different students, and discussing and using the concept efficiently and correctly, it can be said that CCTs can be effectively adapted in relation to the teaching process in terms of the many concepts in the social studies curriculum. However, in the use of CCTs, which should not be forgotten in this process, especially in the change in political and ideological concepts, there is the possibility of encountering strong and intense resistance and the necessity of a long educational process.

Within the scope of the study, it has been deemed appropriate to submit the following suggestions for practitioners and researchers.

- On the social studies course, research can be carried out on the different political concepts (constitution, authority, political party, pluralism, etc.), especially in the upper classes, in order to avoid conceptual misconceptions of CCTs and the influence on conceptual significance.

- Research can be conducted in terms of how CCTs at different grade levels affect attitudes towards social studies lessons and the persistence of achievement.

- CCTs: research on the effects of classification, abstraction, comparison and interpretation processes, which are the basic steps of concept teaching, can be carried out.

- Researches can be conducted based on comparing the effect of CCTs in understanding the concepts and rectifying misconceptions with methodological concept maps, concept nets, analogies, significance analysis tables and so on.

- Using the misconceptions encountered frequently on social studies courses and workbooks, the addition of CCTs and the active use of teachers in educational processes can be achieved

\section{References}

Aladağ, S. \& Yılmaz, E. (2014). Kavramsal değişim metinlerinin öğrencilerin sosyal bilgiler dersindeki kavram yanılgılarını gidermeye etkisi. Trakya Üniversitesi Sosyal Bilimler Dergisi, 16(2),163-176.

Akbaş, Y., Koca, H. \& Cin, M. (2012). Ortaöğretim 9. Sınıf öğrencilerinin iklim ve hava durumu kavramlarıyla ilgili yanılgılarını gidermede kavramsal değişim yaklaşımının etkinliği. Doğu Coğrafya Dergisi, 17(27), 23-42.

Akpınar, M. (2012). Bağlam temelli yaklaşımla yapılan fizik eğitiminde kavramsal değişim metinlerinin ögrenci erişisine etkisi (Unpublished Doctoral thesis.). Available from Turkey Digital Theses database. (Record No.317132.)

Akgül, P. (2010). Üstkavramsal faaliyetlerle zenginleștirilmiş kavramsa Ideğişim metinlerinin fen bilgisi öğretmen adaylarının"Isı ve sicaklık"konusundaki kavramsal anlamalarına etkisi (Unpublished Graduate thesis). Available from Turkey Digital Theses database. (Record No. 277999.)

Akşit, i. (2016). 7. sınıf sosyal bilgiler dersi Türk tarihinde yolculuk ünitesinde geçen bazı kavramların öğrenilmesi sürecinde karşılașılan sorunların belirlenmesi ve çözümüne yönelik bir eylem araştırması (Unpublished Doctoral thesis.). Available from Turkey Digital Theses database. (Record No. 426468.)

Aladağ, S. \& Yılmaz, E. (2014). Kavramsal değişimmetinlerinin öğrencilerin sosyal bilgiler dersindeki kavram yanılgılarını gidermeye etkisi. Trakya Üniversitesi Sosyal Bilimler Dergisi,16(2),163-176.

Altuntaş Aydın, M. (2011). Model ve kavramsal değişim metinlerinin birlikte kullanılmasının ilköğretim 7. Sınıf öğrencilerinin "Atomun Yapısı" konusunu anlamaları üzerine etkisi (Unpublished Graduate thesis.). Available from Turkey Digital Theses database. (Record No. 300414.)

Anderson, C.W. \& Smith, E.L. (1987). Teaching science. In Richardson-Koehler, V. (Ed.). Educators' Handbook: A Research Perspective (84-111). White Plains, NY: Longman.

Bal, M.S. \&Akış, A. (2010). Sosyal bilgiler dersi “insanlar ve Yönetim" ünitesinde karşılaşılan kavram yanılgıları. e-Journal of New World Sciences Academy, 5(4),2061-2070.

Broughton, S. H., Sinatra, G. M., \& Nussbaum, E. M. (2013). "Pluto has been a planet my whole life!" Emotions, attitudes, and conceptual change in elementary students' learning about Pluto's reclassification. Research in Science Education, 43(2), 529-550.

Büyüköztürk ş. (2012). Örnekleme yöntemleri. Retrieved from: http://w3.balikesir.edu.tr/ msackes/wp/ wp-content/uploads/2012/03/BAY-Final-Konulari. pdf.

Chambers, K.S.\& Andre, T. (1997). Gender, prior knowledge, interest and experience in electricity and conceptual change text manipulations in learning about direct current. Journal of Research in Science Teaching, 34, 107-123.

Chen, C.C., Lin, H.S. \& Lin, M.L. (2002). Developing a twotier diagnostic instrument to assess high school students' understanding-the formation of images by a plane mirror. Proceedings of the National Science Council, 12(3), 106-121. 
Çaycı, B. (2007). Kavram öğreniminde kavramsal değişim yakIaşımının etkililiğininin celenmesi (Unpublished Doctoral thesis.). Available from Turkey Digital Theses database. (Record No. 189747).

Demir, M. (2010). Üst kavramsal faaliyetlerle zenginleştirilmiş kavramsal değişim metinlerinin fen bilgisi öğretmen adaylarının kuvvet ve hareket konularını anlamalarına etkisi (Unpublished Graduate thesis.). Available from Turkey Digital Theses database. (Record No. 279590.)

Doğan, O. (2007). Illköğretim 5. Sınıf sosyal bilgiler dersi 'Bir ülke bir bayrak' ünitesindeki kavramların öğrenilmesinin bazı değişkenler açısından incelenmesi (Unpublished Graduate thesis.). Available from Turkey Digital Theses database. (Record No. 206429.)

Dole, J.A. (2000). Readers, texts and conceptual change learning. Reading and Writing Quarterly, 16, 99-118.

Driver, R. \& Easley, J. (1978). Pupils and paradigms; a review of literature related to concept development in adolescent science students. Studies in Science Education, $5,61-84$.

Duit, R.\&Treagust, D. (2003). Conceptual change: a powerful framework for improving science teaching and learning. International Journal of Science Education, 25, 671-688

Dündar, H. (2011). Sosyal bilgilerde kavram öğretimi. Tay, B. and Öcal, A. (Eds.). Ankara: Pegem Akademi.

Fensham, P.J. (1988). Approaches to the teaching of STS in science education. International Journal of Science Education, 10(4), 346-356.

Gonzalez, F.M. (1997). Diagnosis of Spanish primary school students' common alternative science concepts. School Science and Mathematics, 97(2),68-74.

Halloun, I.A. \& Hestenes, D. (1985). Common sense concepts about motion. American Journal of Physics, 53(11), 1056-1065.

Helm, H. (1980). Misconceptions in physics amongst south African students. Physics Education, 15, 92-105.

Hewson, M.G. \& Hewson, P.W. (1983). Effect of instruction using students' prior knowledge and conceptual change strategies on science learning. Journal of Research in Science Teaching, 20(8), 731-743.

Guzzetti, B.J. (2000). Learning counter-intuitive science concepts: what have we learned from over a decade of research? Reading \& Writing Quarterly, 16, 89-98.

Karasar, N. (2009). Bilimsel araştırma yöntemi. Ankara: Nobel.

Karataş, F. Ö., Köse, S. \& Coştu, B. (2003). Öğrenci yanılgılarını ve anlama düzeylerini belirlemede kullanılan iki aşamalı testler. Pamukkale Üniversitesi Eğitim Fakültesi Dergisi, 13(1), 54-69.

Kılıçoğlu, G. (2011). Sosyal bilgiler derslerinde kavramsal değişim metinlerinin kavram yanılgılarını giderme üzerine etkisi (Unpublished Doctoral thesis.). Available from Turkey Digital Theses database. (Record No. 298398.)

Kilbane, C. R., \& Milman, N. B. (2013). Teaching models: Designing instruction for 21st century learners. NY: Pearson.

Klausmeier, H.J. (1992). Concept learning and concept teaching. Educational Psychologist, 27(3),267-286.
MoNE (2005). Sosyal bilgiler programı. Available from: http:// ttkb.meb.gov.tr/program2.aspx. Retrieved on: 12 April 2017.

MoNE (2018). Sosyal bilgiler programı. Available from: http:// mufredat.meb.gov.tr/Programlar.aspx. Retrieved on: 7 March 2018.

Memişoğlu, H. \&Tarhan, E. (2016). Sosyal bilgiler öğretmenlerinin kavram öğretimine ilişkin görüşleri. Eğitim ve Öğretim Araştırmaları Dergisi, 5(2), 6-20.

Morgan, C.T. (1977). Psikolojiye giriş ders kitabı. Çev: Hüsnü Arıcı vd. Ankara: Meteksan.

Mortimer, E.F. (1995). Conceptual change or conceptual profile change? Science and Education, 4, 267-285.

Nakhleh, M.B. \& Krajcik, J.S. (1994). Influence of levels of information as presented by different technologies on students understanding of acid, base and $\mathrm{pH}$ concepts. Journal of Research in Science Teaching, 34(10),1077-1096.

Öner, A.F. (2011). Kavramsal değişim metinlerinin etkiliği: Meta analiz çalışması (Unpublished Graduate thesis.). Available from Turkey Digital Theses database. (Record No. 279751.)

Öner, N. (1986). Klasik mantık. Ankara Üniversitesi İlahiyat Fakültesi No. 173.

Özdemir, A.M. (2012). ilköğretim 5. sınıf fen ve teknoloji dersi ünitelerinde kavramsal değişim yaklaşımının öğrenci başarısına etkisinin incelenmesi (Unpublished Doctoral thesis.). Available from Turkey Digital Theses database. (Record No. 310961.)

Pintrich, P.R., Marx, R.W. \& Boyle, R.B. (1993). Beyond cold conceptual change: the role of motivational beliefs and classroom contextual factors in the process of conceptual change. Review of Educational Research, 63(2):167-199.

Posner, G.J., Strike, K.A., Hewson, P. W. \& Gertzog, W.A. (1982). Accommodation of a scientific conception: toward a theory of conceptual change. Science Education, 66, 211-227.

Sarı Ay, Ö. (2011). illköğretim 8. Sınıffen ve teknoloji dersi “Maddenin Halleri ve Isı"ünitesinde belirlenen kavram yanılgılarının giderilmesinde kavramsal değişim metinleri kullanımının etkisi ve öğrenci görüşleri (Unpublished Gradual thesis.). Available from Turkey Digital Theses database. (Record No. 308425.)

Smith, J.P., Disessa, A.A. \& Rochelle, J. (1993). Misconceptions reconceived: a constructivist analysis of knowledge in transition. The Journal of Learning Sciences, 3(2), 115-163.

Şarlayan, R. (2017). Kavramsal değişim metinlerinin sosyal bilgiler dersindeki kavram yanılgılarının giderilmesine etkisi (Unpublished Graduate thesis.). Available from Turkey Digital Theses database. (Record No. 477316.)

Tabachnick, B.G. \& Fidell, L.S. (2007). Using Multivariate Statistics. Allyn \& Bacon/Pearson Education.

Topçubaşı, T. \&Polat, S. (2014). Sosyal bilgiler öğretiminde kavram karikatürlerinin öğrenci başarısına etkisi. International Journal of New Trends in Arts, Sports \& Science Education, 3(2), 48-61. 
Treagust, D.F. (1988). Development and use of diagnostic tests to evaluate students' misconceptions in science. International Journal of Science Education, 10(2), 159-169.

Türksever, Ö. (2013). Coğrafya dersi 10. Sınıf çevre ve toplum öğrenme alanında kavramsal değişim yaklaşımının öğrencilerin akademik başarısına etkisi (Unpublished Doctoral thesis.). Available from Turkey Digital Theses database. (Record No. 349919.)

Vosniadou, S. (1994). Capturing and modeling the process of conceptual change. Learning and Instruction, 4 45-69.

Vosniadou, S. (2007). Re-framing the conceptual change approach and its re-framing. In Vosniadou, S, Baltas, A and Vamvakoussi, X (Eds.).Re-framing the Conceptual Change Approach in Learning and Instruction. Oxford: Elsevier.

Wang, T.\&Andre, T. (1991). Conceptual change text versus traditional text application questions versus no questions in learning about electricity. Contemporary Educational Psychology, 16,103-116

\section{Notes}

${ }^{1}$ This is referred to as assimilation and accommodation by Posner at al. (1982), enrichment and revision by Vosniadou (1994), and weak and strong knowledge restructuring by Duit and Treagust (2003).

${ }^{2}$ Those concepts that remain outside the scientific reality can be referred to as misconceptions (Nakhleh \& Krajcik, 1994; Helm,1980), preconceptions (Anderson \& Smith,1987), alternative conceptions (Gonzalez,1997), naive conceptions (Fensham,1988), alternative frameworks (Driver \& Easley,1978), common-sense conceptions (Halloun \& Hestenes, 1985) and spontaneous knowledge (Treagust,1988). In this research, "alternative concepts", having a more general and widespread use, are preferred.

${ }^{3}$ Conceptual change texts are abbreviated as CCT throughout the study.

${ }^{4}$ Fourth-grade Social Science Workbook (2014-2015, Evrensel Yayıncılık); Fourth-grade Social Science Workbook (2014-2015, MEB Yayınları); Fourth-grade Social Science Workbook (2015-2016, DikeyYayıncılık); Fourth-grade Social Science Workbook (2016-2017, KozaYayınları). 